\title{
Toksisitas Akut Ekstrak Etanol Daun Bidara (Ziziphus spina-christi L.) berdasarkan Gambaran Morfologi dan Histologi Hati Mencit
}

\section{Acute Toxicity of Bidara Leaf (Ziziphus spina-christi L.) Ethanol Extract based on Morphological and Histological Images of Mice Liver}

\author{
Nur Syamsi Dhuha ${ }^{1 *}$ Haeria $^{1}$, Hardyanti Eka Putri ${ }^{2}$ \\ 1Jurusan Farmasi, Fakultas Kedokteran dan Ilmu Kesehatan, UIN Alauddin Makassar \\ Jalan HM Yasin Limpo No. 36 Sungguminasa Kabupaten Gowa \\ ${ }^{2}$ Mahasiswa Prodi Farmasi, Fakultas Kedokteran dan Ilmu Kesehatan, UIN Alauddin Makassar \\ Jalan HM Yasin Limpo No. 36 Sungguminasa Kabupaten Gowa \\ Kontak*: nursyamsi.dhuha@uin-alauddin.ac.id
}

\begin{abstract}
ABSTRAK
Daun bidara (Ziziphus spina-christi L.) digunakan sebagai obat tradisional. Daun Bidara memiliki khasiat antioksidan, antiinflamasi, antimikroba, antifungi dan mencegah timbulnya tumor. Penggunaan daun bidara berkhasiat berdasarkan bukti empiris, tetapi belum diteliti keamanannya. Penelitian ini bertujuan untuk mengetahui batas toksisitas ekstrak etanol daun bidara berdasarkan gambaran morfologi dan histologi hati mencit. Prosedur dimulai dengan ekstraksi simplisia daun bidara secara maserasi menggunakan pelarut etanol 70\%. Mencit sebanyak 15 ekor yang dibagi menjadi lima kelompok. Kelompok I (kontrol) yang hanya diberi Na-CMC 1\%. Kelompok II, III, IV, dan V adalah kelompok perlakuan yang diberi ekstrak etanol daun bidara dengan dosis berturut-turut 60, 200, 600, dan $2000 \mathrm{mg} / \mathrm{kgBb}$. Pemberian ekstrak dilakukan per oral selama 14 hari kemudian pada hari ke-15, toksisitas diamati. Toksisitas diamati dari preparat histologi hati mencit berdasarkan nilai kerusakan parenkimatosa, hidropik dan nekrosis. Ekstrak etanol daun bidara memberi pengaruh pada gambaran morfologi yaitu pada warna dan berat basah hati mencit serta adanya kerusakan histopatologi. Batas toksisitas diamati pada dosis $600 \mathrm{mg} / \mathrm{kgBB}$.
\end{abstract}

Kata kunci: Daun bidara, toksisitas, morfologi, histologi.

\begin{abstract}
Bidara leaf (Ziziphus spina-christi L.) have been used as traditional medicine. Bidara leaves have antioxidant, anti-inflammatory, antimicrobial, antifungal properties and prevent tumors activities. The use of bidara leaves is based on empirical evidence, but its safety has not been investigated. This aims of this study is to determine the toxicity limit of bidara leaf ethanol extract based on morphological and histological characterisctics of mice liver. The procedure begins with bidara leaf simplicia extraction by maceration method with $70 \%$ ethanol solvent. Fifteen mice were divided into five groups. First group (control) were only given Na-CMC 1\%. Groups II, III, IV, and $V$ are the treatment groups that were given ethanol extracts of bidara leaves, respectively doses, 60, 200, 600, and $2000 \mathrm{mg} / \mathrm{kgBW}$. The extract was administered orally for 14 days. Then on 15th day, the toxicity observed. Toxicity was observed from mice liver histology based on parenchymatosa, hydropic and necrotic damage values. The ethanol extract of bidara leaves gives an effect on the morphological character, namely the color and weight of the wet liver of mice and the histopathological damage. Toxicity limits were observed at doses of $600 \mathrm{mg} / \mathrm{kgBW}$.
\end{abstract}

Keywords: Bidara leaf, toxicity, morphology, histology.

\section{PENDAHULUAN}

Tanaman Bidara memiliki kandungan fenolat dan flavonoid yang kaya akan manfaat. Senyawa fenolat adalah senyawa yang mempunyai sebuah cincin aromatik dengan satu atau lebih gugus hidroksi, senyawa yang berasal dari tumbuhan yang memiliki ciri sama, yaitu cincin aromatik 
yang mengandung satu atau lebih gugus hidroksil (Harbone, 1987). Tanaman bidara, yang kaya akan kandungan senyawa golongan fenolat, berkhasiat antara lain sebagai antioksidan, antiinflamasi, antimikroba, antifungi dan mencegah timbulnya tumor (Prior, 2003). Bidara berkhasiat untuk melindungi sel DNA manusia yang disebabkan oleh kerusakan dari radiasi actinic, (Abdel-Galil \& El-Jissly, 1991).

Meski telah banyak penelitian tentang kandungan kimia daun bidara, penggunaan daun bidara secara klinis masih berdasarkan bukti empiris saja sehingga masih dibutuhkan penetapan khasiat farmakologi dan uji toksisitas ekstraknya. Penelitian mengenai toksisitas perlu dilakukan untuk melindungi masyarakat dari efek yang mungkin merugikan. Sebagai langkah awal untuk mengetahui potensi toksik suatu zat, maka dilakukan uji toksisitas (Astri, Sitorus, Sigit, \& Sujatno, 2012). Uji toksisitas akut adalah tata cara tertentu yang dirancang untuk menentukan dosis letal median suatu zat dan kemungkinan mekanisme kerja dan target organ (Priyanto, 2010). Secara sederhana toksisitas dapat diartikan sebagai kemampuan suatu senyawa yang dapat menimbulkan efek berbahaya atau penyimpangan mekanisme biologi pada suatu organisme (Agus \& Rasmaya, 2006).

Efek toksik obat-obatan dapat diamati dari morfologi dan histologi hati, dikarenakan perannya yang sentral dalam metabolisme semua obat dan bahan-bahan asing yang masuk dalam tubuh. Hati akan mengubah struktur obat yang lipofilik menjadi hidrofilik sehingga mudah dikeluarkan dari tubuh melalui urin atau empedu (Dewoto, 2007). Hati menjadi organ sasaran karena beberapa hal, seperti bagian besar zat toksik memasuki tubuh melalui sistem gastrointestinal, dan diserap, toksikan dibawa oleh vena porta hati ke hati. Hati mempunyai banyak tempat pengikatan. Kadar enzim yang memetabolisme dalam hati juga tinggi (terutama sitokrom P-450) ini yang membuat besar toksikan menjadi kurang toksik dan mudah larut dalam air, dan karenanya lebih mudah diekskresikan. Tetapi beberapa kasus, efek toksik dapat menginduksi lesi yang bersifat sentrilobuler yang dikaitkan dengan kadar sitokrom P-450 yang lebih tinggi (Priyanto, 2010).

Berdasarkan uraian tersebut, maka perlu diteliti toksisitas akut dari ekstrak etanol daun bidara dengan menggunakan mencit sebagai hewan coba. Setelah pemberian ekstrak, diperlukan pengamatan lebih lanjut terhadap morfolog dan histologi organ hati. Dari penelitian ini diharapkan dapat diperoleh batas aman penggunaan ekstrak bidara agar tidak terjadi efek toksik.

\section{METODE PENELITIAN}

\section{Alat dan Bahan}

Alat-alat yang digunakan dalam penelitian ini adalah gunting anatomis, kandang hewan coba, kanula mencit, kompor listrik $\left(\right.$ akebonno $\left.^{\circledR}\right)$, meja lilin, mikroskop (Nikon 
Eclipse E100), neraca analitik (Kern®), pisau bedah, rotary evaporator $\left(\right.$ Heidolph $\left.^{\circledR}\right)$, sendok tanduk, timbangan, toples, dan wadah (mangkok). Bahan yang digunakan adalah air suling, daun bidara (Ziziphus spina-christi L.), larutan etanol 70\%, larutan Na CMC 1\%, mencit (Mus musculus) jantan dan pewarna hematoksilin-eosin.

\section{Ekstraksi Sampel}

Simplisia daun bidara sebanyak $500 \mathrm{~g}$ dimaserasi dengan pelarut etanol 70\% selama $2 \times 24$ jam. Simplisia yang telah dimaserasi disaring hingga diperoleh filtrat. Filtrat tersebut kemudian diuapkan dengan menggunakan alat rotary evaporator sehingga dihasilkan ekstrak kering daun bidara.

\section{Uji Toksisitas Akut pada Mencit}

Hewan coba dikelompokkan menjadi 5 kelompok dan masing-masing kelompok terdiri dari 3 ekor mencit jantan. Kelompok I sebagai kontrol negatif, mencit diberikan $\mathrm{Na}$ CMC. Kelompok II, III, IV, dan V diberikan ekstrak daun bidara dengan dosis berturutturut 60, 200, 600, dan $2000 \mathrm{mg} / \mathrm{kg} \mathrm{Bb}$. Ekstrak disuspensikan dengan Na CMC 1\%, diberikan secara peroral selama 14 hari. Pengamatan pada mencit dilakukan pada hari ke-15 meliputi pengamatan (1) makroskopik, terhadap morfologi hati mencit seperti warna dan penampilan sering dapat menunjukkan sifat toksisitas (Dorland, 2002); dan (2) mikroskopik, pada berbagai jenis kelainan histologi, seperti perlemakan, nekrosis,
Tabel 1. Pengamatan morfologi dan makroskopi hati mencit

\begin{tabular}{cccc}
\hline Kelompok & Repli- & \multicolumn{2}{c}{ Pengamatan } \\
\cline { 3 - 4 } & kasi & Warna & Tekstur \\
\hline 1 & 1 & Merah Pekat & Licin \\
NaCMC 1\% & 2 & Merah Pekat & Licin \\
& 3 & Merah Pekat & Licin \\
\hline 2 & 1 & Merah & Licin \\
Dosis 60 & 2 & Merah & Licin \\
mg/kgBB & 3 & Merah Pucat & Licin \\
\hline 3 & 1 & Merah Pucat & Licin \\
Dosis 200 & 2 & Merah & Licin \\
$\mathrm{mg} / \mathrm{kgBB}$ & 3 & Merah Pucat & Licin \\
\hline 4 & 1 & Merah Pucat & Licin \\
Dosis 600 & 2 & Merah Pucat & Licin \\
$\mathrm{mg} / \mathrm{kgBB}$ & 3 & Merah Pucat & Licin \\
\hline 5 & 1 & Merah Pucat & Licin \\
Dosis 2000 & 2 & Merah Pucat & Licin \\
$\mathrm{mg} / \mathrm{kgBB}$ & 3 & Merah Pucat & Licin \\
\hline
\end{tabular}

sirosis, nodul hiperplastik, dan neoplasia (Frank, 2010). Pada hari ke-15 mencit dieuthanasia kemudian diambil organ hati mencit untuk diamati secara makroskopik dan mikroskopik. Jaringan hati diamati secara makroskopik berdasarkan warna dan tekstur. Jaringan hati selanjutnya diolah mengikuti metode baku histologi dengan menggunakan pewarna hematoksilin dan eosin untuk diamati karakteristik mikroskopiknya dengan mikroskop. Setiap organ hati dibuat menjadi 3 preparat dari tiap kelompok. Sasaran yang dibaca dari preparat histologi hati mencit adalah nilai kerusakan parenkimatosa, hidropik dan nekrosis. Hasil penelitian dianalisis dengan menggunakan software SPSS dengan uji Analysis of Variance (ANOVA).

\section{PEMBAHASAN}

Hasil pengamatan makroskopis menunjukkan bahwa pemberian ekstrak etanol daun bidara secara akut berpengaruh 


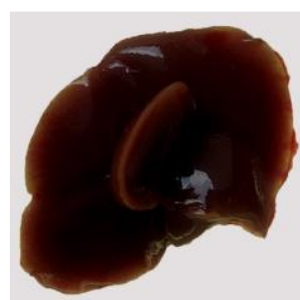

Kontrol negatif



$60 \mathrm{mg} / \mathrm{kg} \mathrm{BB}$

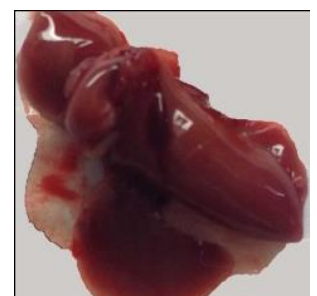

$200 \mathrm{mg} / \mathrm{kg} \mathrm{BB}$

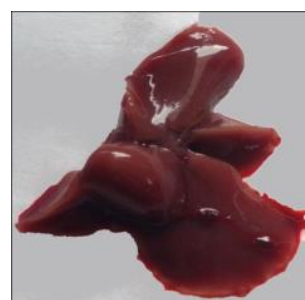

$600 \mathrm{mg} / \mathrm{kg} \mathrm{BB}$

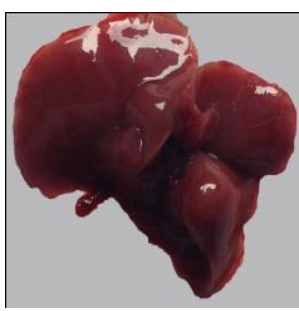

$2000 \mathrm{mg} / \mathrm{kg} \mathrm{BB}$

Gambar 1. Morfologi hati mencit

terhadap gambaran makroskopis hati. Warna hati yang diamati baik pada kelompok kontrol maupun perlakuan berwarna merah kecoklatan atau merah pekat dan merah pucat. Menurut Dorland (2002), hati yang normal terlihat berwarna merah pekat, jika ditekan terasa agak keras dan licin. Degenerasi ringan pada hati tidak berpengaruh pada penampakan makroskopisnya karena hati mempunyai kemampuan regenerasi yang tinggi. Kerusakan jaringan akibat zat-zat toksik memacu mekanisme dimana sel-sel hati mulai membelah dan terus berlangsung sampai perbaikan massa jaringan tercapai.

Gambaran mikroskopik diamati dengan skor perubahan strukur histopatologi sel hati mencit. Tabel 2 memperlihatkan peningkatan kerusakan histologi hati mencit sesuai dengan kenaikan dosis ekstrak daun bidara yang diberikan yaitu pada kelompok 2, 3, 4, dan 5, jika dibandingkan dengan kontrol, walaupun dengan derajat kerusakan yang berbeda. Perbedaan tersebut kemungkinan dipengaruhi oleh beberapa faktor seperti kondisi patologi dan genetik. Kondisi patologi pada mencit termasuk pertahanan tubuh terhadap partikel atau molekul asing yang masuk ke dalam tubuh mencit tersebut. Kondisi-kondisi tersebut memberi pengaruh terhadap penampakan morfologi maupun histologi hati mencit.

Kerusakan paling umum struktur histologi hati mencit yang diberi ekstrak etanol daun bidara adalah degenerasi parenkimatosa. Kerusakan inti adalah perubahan yang terjadi pada sitoplasma meliputi perlemakan, yang ditandai dengan adanya penimbunan lemak dalam parenkimatosa hati, dapat berupa bercak atau pengecatan tidak merata. Pada pengecatan inti terlihat terdesak ke tepi rongga sel terlihat kosong diakibatkan butir lemak yang larut pada saat pemprosesan. Kerusakan lain adalah degenerasi hidropik, khususnya kelompok dosis $2000 \mathrm{mg} / \mathrm{kg}$ BB. Degenerasi hidropik terjadi karena adanya gangguan membran sel sehingga cairan masuk ke dalam sitoplasma, menimbulkan vakuola-vakuola kecil sampai besar. Terjadi

Tabel 2. Pengamatan Histologi dan Mikroskopi Hati Mencit

\begin{tabular}{ccccc}
\hline \multirow{2}{*}{ Kelompok } & \multicolumn{3}{c}{ Replikasi } & Rata- \\
\cline { 2 - 4 } & I & II & III & rata \\
\hline $1(\mathrm{NaCMC} 1 \%)$ & 1 & 1 & 1 & 1 \\
$2(60 \mathrm{mg} / \mathrm{kgBB})$ & 2 & 2 & 2 & 2 \\
$3(200 \mathrm{mg} / \mathrm{kgBB})$ & 2 & 1 & 2 & 1,7 \\
$4(600 \mathrm{mg} / \mathrm{kgBB})$ & 2 & 2 & 3 & 2,3 \\
$5(2000 \mathrm{mg} / \mathrm{kgBB})$ & 3 & 3 & 3 & 3 \\
\hline
\end{tabular}

Keterangan

$1:$ normal

$2:$ degenerasi parenkimatosa

3 : degenerasi hidropik

$4:$ nekrosis 
Sel Normal (skor 1)
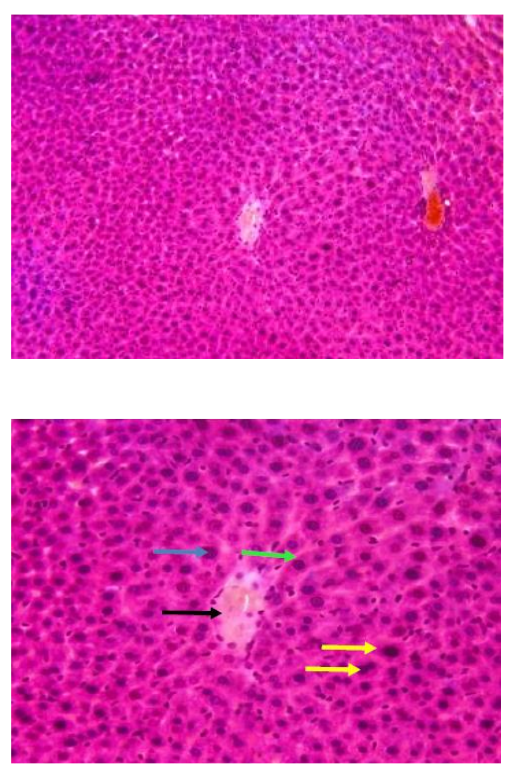

Keterangan: $\rightarrow$ hitam $=$ vena sentral
Degenerasi parenkimatosa



Perbesaran 200x



Perbesaran 400x

$\rightarrow$ hijau $=$ sinusoid

$$
\begin{aligned}
\rightarrow \text { biru } & =\text { inti sel } \\
\rightarrow \text { kuning } & =\text { lempeng sel }
\end{aligned}
$$

Degenerasi hidropik


Gambar 2. Kerusakan histologi hati mencit

akumulasi cairan karena sel yang sakit tidak dapat menyingkirkan cairan yang masuk. Pemberian ekstrak etanol daun bidara dengan dosis hingga $2000 \mathrm{mg} / \mathrm{kg}$ BB tidak memperlihatkan adanya kerusakan dengan skor 4 yaitu nekrosis. Menurut Manggung (2008), kondisi degenerasi parenkimatosa bersifat reversible yaitu memungkinkan adanya regenerasi sel yang baru. Sedangkan pada kondisi degenerasi hidropik bersifat irreversible.

Hasil penelitian menunjukkan pemberian ekstrak daun bidara secara akut mempengaruhi gambaran makroskopis hati, yaitu pada warna dan berat basah hati mencit dan patologi organ. Pemberian ekstrak daun bidara memiliki resiko toksik terhadap hati yaitu perubahan struktur histopatologi sel hati berupa degenerasi hidropik mulai pada konsentrasi ekstrak $600 \mathrm{mg} / \mathrm{kgBB}$ dengan nilai kerusakan hati 3 . Nilai 3 digunakan sebagai batas sebab sifat toksisitas bersifat irreversible.

\section{KESIMPULAN}

Dosis beresiko toksik pada liver mencit dari Ekstrak Bidara adalah $600 \mathrm{mg} / \mathrm{kg}$ BB mencit.

\section{KEPUSTAKAAN}

Abdel-Galil, F., \& El-Jissly, M. (1991). Phytochemistry 30.

Agus, W. M., \& Rasmaya, N. (2006). Buku Ajar Toksikologi Umum. Bali: Jurusan Farmasi Universitas Udayana.

Astri, Y., Sitorus, T., Sigit, J. I., \& Sujatno, M. (2012). Toksisitas Akut per Oral Ekstrak Etanol Daun Dewa (Gynura pseudochina (Lour.) DC) terhadap Kondisi Lambung Tikus Jantan dan Betina Galur Wistar. Majalah Kedokteran Bandung, 44(1). doi:10.15395/mkb.v44n1.71

Dewoto, H. R. (2007). Pengembangan Obat Tradisional Indonesia Menjadi Fitofarmaka. Majalah kedokteran, 57.

Dorland, W. A. (2002). Kamus Kedokteran Dorland (19 ed.). Jakarta: EGC. 
Frank, C. L. (2010). Toksikologi Dasar (2 ed.). Jakarta: UI-Press.

Harbone, J. (1987). Metode Fitokimia terbitan ke-2. Bandung: Penerbit ITB.

Manggung, R. E. (2008). Pengujian Toksisitas Akut Lethal Dose 50 (LD50) Ekstrak Etanol Buah Belimbing Wuluh (AverrhoabilimbiL.) Pada Mencit (Mus musculus albinus). Fakultas Kedokteran Hewan Institut Pertanian Bogor.
Prior, R. L. (2003). Fruit and vegetable in The Prevention of Cellular Oksidative Damage. American Journal of Clinical Nutrition, 78, 570S-578S. doi:10.1093/ajcn/78.3. 570 S.

Priyanto. (2010). Farmakologi Dasar. Depok: Leskonfi (Lembaga Studi dan Konsultasi Farmakologi). 